\title{
Mitä on suomalainen aikuiskasvatustutkimus?
}

\author{
PETRI SALO
}

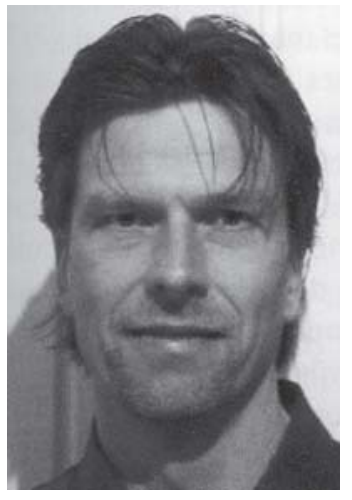

On vierähtänyt vuosikymmen siitä, kun suomalaisen aikuiskasvatustutkimuksen suuntauksia ja sisältöjä pohdittiin Aikuiskasvatuslehden sivuilla. Vuoden 1995 viimeinen numero omistettiin suomalaisen aikuiskasvatustutkimuksen tuolloisen tilan tarkastelulle. Hahmotan kyseisen teemanumeron suomalaisen aikuiskasvatustutkimuksen toisen vaiheen tilinpäätökseksi. Mutta mitä kolmas vaihe ja sille tunnusomainen vahva ekspansio on merkinnyt aikuiskasvatustutkimuksen sisältöjä ajatellen? Tarkastelen artikkelissa Aikuiskasvatuksessa julkaistuja tieteellisiä artikkeleita vuosina 1996-2004.

Ensimmäiselle vaiheelle, joka alkoi kansansivistysopin professuurin perustamisella Yhteiskunnalliseen korkeakouluun vuonna 1946, oli ominaista teoreettis-käsitteellis-filosofisen perustan luominen (Tuomisto 1998). Reilut kolmekymmentä vuotta kestäneen vaiheen lopussa tehtiin myös ensimmäiset laajemmat empiiriset tutkimukset.

Aikuiskasvatustutkimuksen toiseen vaiheeseen siirryttiin alan toisen oppituolin perustamisen myötä vuonna 1980. Helsingin yliopistossa 1980-luvulla kasvanut tutkimuksen toinen sukupolvi laajensi teoreettisesti painottunutta ja vapaaseen sivistystyöhön suuntautunutta tutkimusta selkeästi työelämän tutkimuksen suuntaan. Toinen merkittävä muutos oli metodologinen laaja-alaistuminen.

Suomalaisen aikuiskasvatustutkimuksen kolmanteen vaiheeseen siirryttiin 1990-luvun puolivälissä. Alan uusia oppituoleja perustettiin Turun, Jyväskylän, Joensuun ja Lapin yliopistoihin sekä Åbo Akademin Vaasan yksikköön (ks. Kivinen \& Rinne 1995).

Mutta mitä kolmas vaihe ja sille tunnusomainen vahva ekspansio on merkinnyt aikuiskasvatustutkimuksen sisältöjä ajatellen? Missä aikuiskasvatustutkimusta tehdään ja keiden toimesta? Mitkä ovat suomalaisen aikuiskasvatustutkimuksen tutkimuskohteet? Miten aikuiskasvatusta tut- kitaan? Näihin kysymyksiin pyrin seuraavassa hahmottamaan vastauksia tarkastelemallaAikuiskasvatus-lehdessä vuodesta 1996 vuoteen 2004 julkaistuja tieteellisiä artikkeleita.

\section{Aikuiskasvatustutkimus muualla}

Aikuiskasvatustutkimuksen tilaa ja luonnetta, lähinnä anglosaksisessa viitekehyksessä, on tarkasteltu muutamassa melko tuoreessa katsauksessa. Rubensson (2000) päivitti taannoin alun perin 1980-luvun alussa laatimansa kartan pohjoisamerikkalaisesta ja eurooppalaisesta aikuiskasvatustutkimuksesta. Hän toteaa, että vaikka aikuiskasvatustutkimuksessa on seurattu yhteiskuntatieteissä tapahtuneita muutoksia sekä omaksuttu poststrukturalistisia, postmoderneja ja feministisiä lähtökohtia ja näkökulmia, on tutkimus säilyttänyt itselleen ominaisen käytäntölähtöisen ja -vetoisen peruslähtökohdan. Kolikon toiselta puolelta löytyy eri yhteyksissä tiedostettu ja todettu oman teoriaperustan puute.

Talouselämässä sekä työmarkkinoilla tapahtuneiden muutosten merkitys on selkeästi havaittavissa aikuiskasvatustutkimuksessa. Kiinnostus valtiojohtoista koulutuspolitiikkaa kohtaan on saanut väistyä työllistettävyyteen, työmarkkinoilla tarvittaviin valmiuksiin sekä oppiviin organisaatioihin kohdistuvan tutkimuksen tieltä. 
Samanaikaisesti aikuisoppimisen käsite on laaja-alaistunut. Boydin ja Appsin (1980) aikoinaan konkretisoima toive (tai vaatimus?) oman teoriaperustan luomisesta on korvautunut postmoderneilla pyrkimyksillä poikki- ja monitieteelliseen otteeseen.

Rubensson jakaa yksittäiset tutkimukset kolmeen selkeästi toisistaan erottuvaan ryhmään; hyvin perusteltuihin normatiivisiin aikuiskasvatuskäytäntöjä sekä sosiaalisten olosuhteiden parantamista koskeviin lausuntoihin, yksittäisiin ja pienimuotoisiin empiirisiin tutkimuksiin sekä laajempiin teoreettis-filosofisiin pohdintoihin. Rose (2000), joka pohtii aikuiskasvatustutkimuksen tilaa pohjoisamerikkalaisesta näkövinkkelistä, on Rubenssonin kanssa pitkälti samoilla linjoilla. Yksittäisiin muutos- ja kehityshankkeisiin keskittynyt kuvaileva tutkimus, jolla on pyritty hyvien käytäntöjen tunnistamiseen, on laajentanut aikuiskasvatustutkimusta mitä moninaisempiin asiayhteyksiin ja viitekehyksiin.

Tutkimustuloksia ei kuitenkaan ole juurikaan pyritty tai kyetty hyödyntämään yksittäisten viitekehysten ulkopuolella. Näin ollen niiden tuloksista ei ole pystytty johtamaan laaja-alaisia teoreettisia yleistyksiä. Aikuiskasvatuksesta onkin tullut yhä hankalammin rajattavissa ja määriteltävissä oleva tieteenala. Oman tieto- ja teoriaperustan luomisessa ei ole edistytty, pikemminkin päinvastoin.

Tieteenalalle ominainen hajanaisuus koskee tänään yhä enenevässä määrin myös tutkimuskysymysten asetteluja ja muotoiluja. Niitä ei asetella ja muotoilla riittävän yhtenäisesti ja johdonmukaisesti. Rose toteaa, ehkä hiukan kärjistäen, tendenssin amerikkalaisissa aikuiskasvatusjournaaleissa olevan empiirisen tutkimusten korvaamisen pelkästään teoreettisilla pohdinnoilla. Tämän hän tulkitsee tutkijoiden vastuun pakoiluksi. Vastuu aikuiskasvatuskentän käytännön ongelmien tunnistamisesta ja ratkaisemisesta onkin siirtynyt yhä selkeämmin kentän toimijoille.

Bron (2005) puolestaan tarkastelee eurooppalaista aikuiskasvatustutkimusta. Hänen mukaansa tarkastelunäkökulma on vaihtunut kahden viime vuosikymmenen aikana makrotasolta mikrotasolle. Syyt ovat kahtalaiset. Ensinnäkin aikuisia ei enää tarkastella opetuksen kohteina, vaan itsenäisinä omasta oppimisestaan vastuuta kantamaan kykenevinä toimijasubjekteina. Kyseinen muutos on vaikuttanut myös käsitykseen aikuisopettajasta sekä hänen tehtävästään. Toiseksi tar- kastelutason muutokseen on vaikuttanut yhteiskuntatieteissä laajemminkin herännyt kiinnostus mikrokulttuurisiin kysymyksiin, sosiaalisen vuorovaikutuksen merkitykseen oppimista, sosialisaatiota sekä kehitystä silmällä pitäen. Tämän päivän eurooppalaisen aikuiskasvatustutkimuksen keskeisiksi kohteiksi Bron (emt. 27) listaa seuraavat:

- aikuiskoulutuksen saavutettavuus ja siihen liittyvät prosessit

- erityiset kohderyhmät; maahanmuuttajat, ikääntyvä väestö, naiset

- aikuiskoulutus kansalaisyhteiskunnassa, aktiivinen kansalaisuus, sosiaalinen pääoma

Ehkä keskeisin yhteinen nimittäjä yllämainituille tutkimusteemoille on oppijoiden oman henkilökohtaisen näkökulman korostuminen. Bron kiinnittää huomiota myös tutkimusmetodologisiin muutoksiin. Hypoteesien testaaminen ja todentaminen laajojen survey-ja seurantatutkimusten avulla ovat korvattu tulkinnallisilla, biografisilla ja eksploratiivisilla tutkimusotteilla. Epistemologisista lähtökohdista asiaa tarkasteltaessa tämä on merkinnyt normatiivis-funktionalististen lähestymistavan korvautumista symbolisella interaktionismilla sekä fenomenologialla (vrt. Quigley 1997, 11-12).

Tuomisto (2005, 40-41) kuvaa saman muutoksen siirtymänä positivistis-empiirisestä tutkimusotteesta hermeneuttiseen ja tulkitsevaan tutkimusotteeseen. Hän kirjaa seuraavat muutokset aikamme aikuiskasvatustutkimuksessa. Tutkimus ei enää suuntaudu formaaleissa konteksteissa tapahtuvan ohjatun opiskelun tutkimiseen, vaan työ-ja perhe-elämässä sekä vapaa-ajalla tapahtuvan arkipäiväisen ja spontaanin oppimisen tutkimiseen. Opettamisen, ohjaamisen ja itseohjautuvan oppimisen välisten rajojen hämärtyminen on puolestaan merkinnyt tutkimuksen aiempaa selkeämpää suuntautumista niihin monimuotoisiin prosesseihin, joiden avulla oppimista tuetaan, ohjataan ja arvioidaan. Kolmas muutos liittyy arviointitutkimuksen aiempaa keskeisempään asemaan.

\section{Suomalainen aikuiskasvatustutkimus vuosituhannen vaihteessa}

Tarkastelen seuraavassa suomalaisen aikuiskasvatustutkimuksen tilaa vuosituhannen vaihteessa. Esityksen lähtökohtana on Kivisen ja Rinteen 
(1995, 258-259) vuosikymmen sitten suomalaisen aikuiskasvatustutkimuksen tilaa luotaavassa artikkelissa esittämä oletus. Kyseinen oletus voidaan muotoilla seuraavasti; Aikuiskasvatus -lehdessä julkaistujen artikkelien voidaan olettaa käsittelevän aikuiskasvatustutkimuksen keskeisiä aiheita ja peilaavan siten aikuiskasvatustutkimuksen keskeisiä suuntauksia tarkasteltavana ajankohtana.

Vuosien 1996-2004 Aikuiskasvatus-lehden 36:ssä numerossa julkaistiin yhteensä 163 tiedeartikkelia. Artikkeleilla oli kaiken kaikkiaan 218 kirjoittajaa. Yksittäisten kirjoittajien määrä oli hiukan artikkeleiden määrää suurempi, 175 kappaletta. "Ahkeria" artikkeleiden kirjoittajia (kolmesta viiteen julkaistua artikkelia) oli reilu kahdeskymmenesosa (12 kpl) kaikista kirjoittajista. Hiukan yli viidesosa artikkeleista oli tutkijaryhmien (kaksi tai useampia kirjoittajia) kirjoittamia. Kahta tutkijaa suurempien ryhmien osuus artikkeleista oli vajaa kahdeksan prosenttia

Naisten osuus artikkeleiden kirjoittajista oli hiukan yli 40 prosenttia. Kun 1990-luvun neljän viimeisen vuoden artikkeleiden kirjoittajista vajaa kolmannes (29\%) oli naisia, nousi naisten osuus artikkeleiden kirjoittajista 2000-luvun viiden ensimmäisen vuoden aikana yli puoleen (55\%). Naisten osuus yksittäisistä kirjoittajista koko tarkasteluajanjaksona oli lähes puolet.

\section{Missä suomalaista aikuiskasvatus- tutkimusta tehdään?}

Kivisen ja Rinteen (emt.) tarkastelussa, joka koskee 1980-luvulla Aikuiskasvatuksessa esiteltyä suomalaista aikuiskasvatustutkimusta, yliopistoväen osuus kirjoittajista oli noin puolet. Vuosituhannen vaihteen yhdeksän vuosikerran artikkeleista kolme neljännestä oli yliopistoväen kirjoittamia. Vajaassa viidenneksessä artikkeleista kirjoittaja oli aikuiskasvatuskentän edustaja. Tähän ryhmään kuuluu esimerkiksi ammattikorkeakoulujen, ammatillisten täydennyskoulutuslaitosten, vapaan sivistystyön sekä yrityselämän edustajia. Opetushallinnon sekä muun vastaavan julkisen sektorin osuus kirjoittajista oli neljä prosenttia, kun se 1980-luvulla oli neljännes.

Kohdennettaessa tarkastelu yliopistokentän sisään todentuu ajatus suomalaisen aikuiskasvatustutkimuksen kolmannesta vaiheesta. Aikuiskasvatuksessa 1980-luvulla julkaistuista artikkeleista yli puolet olivat Tampereen yliopiston ja viidennes Helsingin yliopiston tutkijoiden kirjoittamia. Vuosituhannen vaihteeseen tultaessa tamperelaisten osuus oli pudonnut neljännekseen ja helsinkiläisten noussut samaiseen neljännekseen. Jyväskylän yliopiston tutkijoiden asema oli "säilynyt ennallaan". Heitä oli noin kymmenesosa. Turun yliopiston tutkijoiden osuus oli noussut selvästi, viidestä prosentista kolmeentoista prosenttiin. Kivisen ja Rinteen (emt.) tarkastelussa Joensuun, Oulun ja Lapin yliopiston sekä Åbo Akademin edustajat muodostivat pienen viiden prosentin "kirjoittajaklusterin". Vuosituhannen vaihteessa tämän klusterin osuus kirjoittajista oli jo viidennes. Klusterin vahvistuminen johtuu kuitenkin lähes yksinomaan Lapin yliopiston (9\%:ia kirjoittajista) sekä Joensuun yliopiston (8\%:ia kirjoittajista) osuuksien kasvusta.

Tehdäänkö aikuiskasvatustutkimusta omien "kotipesien" eli kasvatustieteellisten tiedekuntien tai -laitosten ulkopuolella? Mikäli mittariksi otetaan tutkimustulosten julkaiseminen Aikuiskasvatuksessa vastaus kuuluu - eipä juuri! Aikuiskasvatuksessa 1980-luvulla julkaistuista artikkeleista viisi prosenttia oli Teknillisen korkeakoulun tutkijoiden kirjoittamia. Vuosituhannen vaihteessa Teknillisen korkeakoulun ja Lappeenrannan teknillisen korkeakoulun tutkijoiden julkaisemia artikkeleita oli yhteensä viisi prosenttia ja kauppakorkeakoulujen (Helsinki ja Turku) tutkijoiden julkaisemia artikkeleita reilu neljä prosenttia. Kun tarkastellaan tutkijaryhmien julkaisemia artikkeleita, voidaan todeta, että viidesosassa tutkijaryhmien julkaisemista artikkeleista ryhmä koostui useamman kuin yhden yliopiston edustajasta.

Aikuiskasvatus-lehden loppuosassa olevien kirjoittajatietojen perusteella oli 85-prosenttisesti mahdollista määritellä kirjoittajan edustama tieteenala. Kaksi kolmasosaa kirjoittajista oli kasvatustieteilijöitä. Yhteiskuntatieteilijöiden osuus oli vajaa kymmenesosa. Psykologian ja valtiotieteiden tieteenaloja edusti kumpaakin noin kuusi prosenttia kirjoittajista. Viidenneksi suurin kirjoittajien edustama yksittäinen tieteenala oli terveystieteet.

Kivinen ja Rinne (emt.) totesivat 1980-lukua koskeneessa tarkastelussaan suomalaisen aikuiskasvatustutkimuksen olevan avoin ulkomaisten mallien ja ajatusten suuntaan. Toteamustaan he perustelivat ulkomaisten kirjoittajien varsin korkealla osuudella. Tarkkaa lukua he eivät tosin maininneet. Tarkastelun alla olevana ajanjakso- 
Taulukko 1. Artikkeleiden kirjoittajien taustaorganisaatiot ja -yhteisöt

\begin{tabular}{|lcclrc|}
\hline & f & \% & & f & \% \\
Helsingin yliopisto & 39 & 24 & Kotimaiset yliopistot/korkeakoulut 162 & 74 \\
Tampereen yliopisto & 38 & 23 & Ulkomaiset yliopistot & 6 & 3 \\
Turun yliopisto & 21 & 13 & Ammattikorkeakoulut & 8 & 4 \\
Jyväskylän yliopisto & 15 & 10 & Muut ammatilliset koulutusorg. & 12 & 6 \\
Lapin yliopisto & 14 & 8 & Vapaan sivistystyön organisaatiot & 5 & 2 \\
Joensuun yliopisto & 13 & 8 & Hallinnon edustajat & 9 & 4 \\
Teknillinen korkeakoulu & 7 & 4 & Muut & 16 & 7 \\
Helsingin kauppakorkeakoulu 5 & 3 & & $\mathbf{2 1 8}$ & $\mathbf{1 0 0 \%}$ \\
Muut yliopistot (5 kpl) & 10 & 6 & & & \\
& $\mathbf{1 6 2}$ & $\mathbf{1 0 0} \%$ & & & \\
& & & & & \\
& & & & &
\end{tabular}

na suomalainen aikuiskasvatustutkimus vaikuttaa kuitenkin tulleen entistä itseriittoisemmaksi. Ulkomaisten kirjoittajien osuus oli nimittäin ainoastaan kolme prosenttia.

\section{Mitä suomalaisessa aikuiskasvatus- tutkimuksessa tutkitaan?}

Artikkeleiden sisältöjä, aikuiskasvatuksen tutkimuskohteita, voidaan tarkastella monista eri lähtökohdista ja monella eri tasolla. Kivisen ja Rinteen (emt.) tarkastelussa hyödynnettiin sekä jakoa vapaa sivistystyö, ammatillinen aikuiskoulutus ja monialueinen yleisartikkeli että perinteistä (aikuis)kasvatustieteen osa-aluejakoa. Mikäli lähtökohdaksi otetaan ensin mainittu kolmijako, voidaan todeta vapaan sivistystyön tutkimuksen joutuneen entistä kapeampaan marginaaliin. Vapaata sivistystyötä käsittelevien artikkelien osuus väheni 15:sta prosentista 5:een prosenttiin. Selkeästi ammatillista koulutusta käsittelevien artikkeleiden osuus putosi noin 40:sta prosentista noin 30:een prosenttiin. Näin ollen voidaan todeta monialueisten yleisartikkeleiden osuuden kasvaneen yli puolesta noin kahteen kolmannekseen.

Aikuiskasvatuksen ja -koulutuksen ilmiöiden tarkastelu sosiologisista näkökulmista vaikuttaa vahvistuneen. Jos osuus oli aiemmin noin kolmannes on se tänään vajaa puolet. Selkeästi psykologisen näkökulmien osuus on puolestaan vähentynyt viidenneksestä noin seitsemäsosaan. Yksiselitteisesti didaktisen osa-alueen osuus on kasvanut muutaman prosenttiyksikön aiemmasta seitsemäsosastaan. Filosofisten artikkeleiden osuus viimeisten kymmenen vuoden artikkeleista oli noin kymmenesosa. Artikkeleiden määritteleminen yksiselitteisesti kasvatustieteiden osa- alueiden perusteella on kuitenkin vaikeaa ja osin jopa mielivaltaista. Kaksi melko yksiselitteistä johtopäätöstä perinteisen osa-aluejaon perusteella voi kuitenkin tehdä. Varsinainen vertaileva kasvatustiede ei globalisaatiopuheestaja Suomen kymmenvuotisesta EU-jäsenyydestä huolimatta ainakaan suomalaisia aikuiskasvatuksen tutkijoita innosta. Sadastakuudestakymmenestä artikkelista vain pari oli teemaltaan vertailevaan aikuiskasvatustieteen osa-alueeseen luettavissa. Tarkastelujakson loppua kohti trendi, jossa suomalaista aikuiskasvatustutkimusta tehdään osana laajempia, usein eurooppalaisia tutkimusprojekteja ja joissa tuloksia on mahdollista vertailla maittain, näytti kuitenkin vahvistuvan. Historiallinen tutkimus ei aikuiskasvatuksen tutkijoita vaikuttanut vuosituhannen vaihteessa säväyttävän. Historiallinen tarkastelutapa oli keskiössä vain muutamassa artikkelissa.

Aikuiskasvatustutkimuksen keskeisiksi teemoiksi on aiemmin määritelty aikuisten oppiminen, opetusmenetelmät ja -metodit, aikuiskoulutuksen suunnittelu ja aikuiskasvatustutkimus ( esim. Blunt \& Lee 1994, 131; Kivinen \& Rinne 1995, 259). En ole pitäytynyt kaavamaisesti aiemmissa teemoitteluissa vaan pyrkinyt aineistolähtöisesti tunnistamaan ja kokoamaan suomalaisen aikuiskasvatustutkimuksen viimeaikaiset kiinnostuksen kohteet. Tämän perusteella olen tunnistanut neljä keskeistä teemaa sekä ne keskeiset käsitteet, jotka teemoja määrittelevät.

- Työelämän ja työmarkkinoiden muutos, keskeisinä teemoina työvoimapoliittinen koulutus, työttömyys, työssä oppiminen sekä koulutuksen ja työelämän vuorovaikutus.

- Organisaatioiden kehittäminen, keskeisinä teemoina kehittämisen välineet ja mallit, tiimit sekä 
oppiva organisaatio.

- Aikuisten opettaminen ja opiskelu, keskeisinä teemoina akateeminen opetus ja opiskelu sekä monimuoto-opetus.

- Aikuinen oppijana; keskeisinä teemoina aikuisuus ja siihen liittyen aikuisoppijuuden sosiaaliset ja yhteiskunnalliset merkitykset sekä oppimisen ja opiskelun merkitykset elämänkulussa.

Näiden teemojen lisäksi artikkeleissa paneuduttiin melko useasti tieto- ja viestintätekniikan hyödyntämiseen aikuisopetuksessa ja -opiskelussa, naisnäkökulmaan/sukupuoleen, asiantuntijuuteen ja osaamiseen, henkilöstön kehittämiseen, yrittäjyyteen ja johtajuuteen.

Aikuiskasvatuksen helmikuussa 2004 järjestettyyn tutkijatapaamiseen kokoontui noin sata suomalaista alan tutkijaa esittämään papereitaan. Eniten papereita esiteltiin teemaryhmissä, joiden teemoina olivat työelämän verkostoissa oppiminen, dialogi, valta ja oppimisen yhteisöt konstruktiivisen aikuiskasvatuksen tukena sekä ammatillinen koulutus ja yrittäjyyskasvatus (Mitä on aikuiskasvatus tänään, 2004). Kyseiset teemat ovat ainakin osin yhteneväiset yllä keskeisiksi tunnistamieni tutkimusteemojen kanssa. Vuoden 2001 tutkijatapaamisessa, jossa esiteltiin vajaa 30 tutkimuspaperia, teemaryhmäjaottelu oli osin aikuiskoulutuksen organisatoristen osa-alueiden mukainen (ammatillinen - vapaa sivistystyö). Edellä mainittujen mukaisia teemaryhmiä edustivat lähinnä teemat sosiaaliset käytännöt ja sukupuoli sekä oppimisympäristöt aikuiskoulutuksessa. Tutkijatapaamiseen perustuvan kirjan toimittajat toteavat kirjaan valikoituneiden artikkeleiden ilmentävän suomalaisen aikuiskasvatustutkimuksen painopisteen siirtymistä "kulttuuristen merkitysten analyysiin, kansainvälisten projektien arviointeihin sekä erityyppisten työympäristöjen ja ammattien tutkimiseen" (Manninen, Kauppi, Puurula \& Kontiainen 2003, 8).

\section{Miten suomalaista aikuiskasvatusta tutkitaan?}

Reijo Raivola (1998) kaipaili ensimmäisessä pääkirjoituksessaan Aikuiskasvatukseen enemmän empiiristen tutkimusten tuloksia esitteleviä artikkeleita. Toteutuiko hänen toiveensa? Vuosien 1996-1999 artikkeleista noin kolmasosassa esiteltiin empiirisen tutkimusten tuloksia. Vastaava osuus vuodesta 2000 vuoteen 2004 julkaistuista artikkeleista oli jo lähes puolet. Kaiken kaikkiaan artikkeleista oli "empiirisiä" nelisenkymmentä prosenttia.

Artikkelin olen määritellyt empiiriseksi, mikäli siinä on suhteellisen yksityiskohtaisesti esitelty rajattuun ja "empiiriseen" aineistoon perustuva kuvaus tai analyysi. Artikkeleiden luokitteleminen teoreettisiksi tai empiirisiksi oli kuitenkin vaikeaa. Empiirisiksi artikkeleiksi en ole luokitellut yleisesti saatavilla olevien tilastotietojen avulla suoritettuja, kirjoittajan teoreettispainotteista argumentointia yleisluontoisesti tukevia kuvailuja, etenkään mikäli aineistoa ei ole kuvattu tai analysoitu erityisesti artikkelissa esitettyjä tutkimustehtäviä silmällä pitäen. Empiirisiksi en ole myöskään lukenut artikkeleita, joissa kuvataan esimerkinomaisesti ja hyvin yleisellä tasolla tiety(i)ssä organisaatioissa toteutettua laatujärjestelmän käyttöönottoa tai arvioinnin organisoimista lähinnä toisen käden lähteisiin tai projekteissa tuotettuihin dokumentteihin viitaten.

Yleisin aineistonkeruumenetelmä oli, kuten ilmeisesti aiemminkin (kts. Vaherva 1995, 269), haastattelu. Artikkeleissa hyödynnettyjen ja analysoitujen haastattelujen määrä vaihteli 5:stä reiluun viiteenkymmeneen, keskiarvon ollessa noin kaksikymmentä. Pienimpiä haastatteluaineistoja esiteltiin ja kuvattiin usein tapausesimerkkeinä. Haastattelut aineistonkeruumenetelmänä yleistyvät tarkastelujakson loppupuolella. Vastaavasti tarkastelujakson alussa Aikuiskasvatuksessa julkaistiin (posti)lomakekyselyaineis-toihin perustuvia empiirisiä tutkimuksia. Kyselyaineistojen koko vaihteli noin sadasta reiluun neljäänsataan, keskiarvon ollessa kahdensadan kieppeillä. Muutamassa artikkelissa esiteltiin myös suurempiin kyselylomakeaineistoihin (useita tuhansia vastaajia) perustuvia kuvauksia ja analyysejä. Tällöin huomio kohdistui kuitenkin vain muutamaan melko rajattuun tutkimuskysymykseen tai esimerkiksi useassa maassa kerätyn aineiston kohdalla Suomessa kerättyyn aineistoon. Tutkimusaineistoina hyödynnettiin melko usein myös dokumenttiaineistoja, keskustelunauhoituksia sekä erilaisia kirjallisesti tuotettuja materiaaleja (esseet, eläytymismenetelmäaineisto).

Tutkimuslomakkeiden avulla koottuja suurempia aineistoja esiteltiin empiirisissä artikkeleissa usein kuvailevasti, prosenttiosuuksien, keskiarvojen tai hajontojen avulla. Vain muutamassa tapauksessa kuvattiin yksityiskohtaisemmin esi- 
Taulukko 2. Yleisimmät aineistonkeruumenetelmät "empiirisissä artikkeleissa" (66 kpl)

\begin{tabular}{|lcc|}
\hline & $\mathbf{f}$ & $\mathbf{\%}$ \\
Haastattelut & 28 & 42 \\
Lomakkeet & 18 & 27 \\
Dokumentit & 13 & 20 \\
Keskustelunauhoitukset & 8 & 12 \\
Kirjoitukset, esseeet & 6 & 9 \\
Havainnointi & 3 & 5 \\
\hline
\end{tabular}

merkiksi Lisrel, faktori- tai MDS-analyysiin perustuvia tutkimustuloksia. Haastatteluaineistojen analyysivälineinä mainittiin tai esiteltiin useimmiten fenomenografia ja muutamassa tapauksessa grounded theory-menetelmä.

Ainakin jossain määrin kriittisenä havaintona totean sen, että vajaassa neljänneksessä artikkeleista tutkimusmetodologisten lähtökohtien esittely ja pohdinta sekä spesifin aineistonanalyysimenetelmän kuvaus puuttui lähes kokonaan. Kyseisissä artikkeleissa tyydyttiin joko aineiston hyvin yleisluontoiseen kuvaukseen tai muutaman case-esimerkin esittelyyn. Mielenkiintoinen havainto on myös se, että esimerkkejä toimintatutkimuksista löytyi vain muutama. Toimintatutkimuksellisesta tutkimusotteesta kun on (esim. Quigley 1997, 5) hahmoteltu niin perinteisen aikuiskasvatustutkimuksen haastajaa kuin sille tyypillisen teoria-käytäntö jännitteen laukaisijaa.

\section{Kokoavia huomioita}

Suomalaisella aikuiskasvatustutkimuksella ei mene huonosti. Tutkimus on selkeästi laajentunut kahden perinteisen kotipesän ulkopuolelle. Sukupuolten ja ehkä sukupolvienkin välinen tasa-arvo on toteutumaan päin. Tutkimusteemat jakautuvat melko tasapuolisesti yksilö-, organisaatio- ja yhteiskuntatasoille. Tutkimus on sekä teoreettista että empiiristä. Tutkimusaineistoja kerätään ja analysoidaan monin työkaluin. Monija poikkitieteellisyyttä toteutetaan ehkä kuitenkin enemmän aikuiskasvatustieteen sisällä kuin tekemällä yhteistyötä muiden tieteenalojen edustajien kanssa.

Aikuiskasvatustutkimuksen, sen tutkimuskohteiden ja niiden tutkimisen, on väitetty olevan muutostilassa (esim. Mohorcic Spolar 2001). Filanderin $(2005,215)$ mukaan aikuiskasvatustutkimus heijastelee yhteiskunnallisen keskustelun taitekohtaa. Vastakkain asettuvat uusliberalisti- set yksilön valinnanvapautta ajavat linjaukset sekä kriittiset, eriarvoisuuksiin huomionsa kiinnittävät näkökulmat. Belzer ja St. Clair (2005, 1394-1396) väittävät 1980-luvulla tapahtuneen tutkimusparadigmamuutoksen, jonka seurauksena poststrukturalistiset, postmodernit, kriittiset ja feministiset tutkimusotteet vahvistuivat, tulleen jo tiensä päähän. Tien päässä saattaa odottaa konservatismia heijasteleva postpositivistinen aikuiskasvatustutkimus.

Atlantin takaa ja Euroopan mantereelta puhaltelevien tuulten vaikutus näkyy eritoten tavassa hahmottaa aikuiskasvatustutkimusta, tutkimusotteissa sekä tutkimuskohteiden valinnassa ja rajauksessa. Rubenssonin (2000) tutkimustyylillinen kolmijako, normatiiviset aikuiskasvatuskäytäntöjä koskevat lausunnot, pienimuotoiset empiiriset tutkimukset sekä yhteiskunnallis-filosofiset pohdinnat, pätee nähdäkseni myös suomalaiseen aikuiskasvatustutkimukseen. Jaan osittain Rosen (2000) huolen yksittäisten ja tiukasti tiettyyn viitekehykseen rajattujen tutkimusten annista ja merkityksestä aikuiskasvatustieteeksi kutsutulle tieteenalalle. Huoleni taustalta löytyy ehkä jo kovasti vanhakantainen ideaali omasta vahvasta teoriaperustasta, aikuiskasvatuksen sekä myös aikuiskasvatustutkijan omasta tutkimusidentiteetistä.

Viimeaikaisen tiedepoliittisen keskustelun julkipuheessa yhä useammin esiintuotu moni-ja poikkitieteellisyyden ihanne asettuu kuitenkin vahvan ja itseriittoisen aikuiskasvatustieteen haastajaksi. Vai asettuuko? Jos tieteenala on jo sinällään monitieteinen. Aiemmin paheksutusta muilta lainaamisesta (Boyd \&Apps 1980) on ehkä tullut poikkitieteellinen hyve (Rubensson 2000). Nähtävillä oleva tutkimusteemojen ja -otteiden monipuolistuminen sekä siirtyminen metodisesta monismista pluralismiin (Vaherva 1995, 269) saattaa johtaa paradigmaattiseen kirjavuuteen ja monenlaiseen yrittämiseen (Rantalaiho 1995, 72).

Elämme monimuotoisessa ja dynaamisessa ajassa, jossa pelkästään omiin kengänkärkiin tuijottelulla väitetään olevan kohtalokkaat seuraukset. Aikuiskasvatuksen tutkijoiden onkin ehkä syytä nostaa katseensa ylös, "skannata ja scrollata" omaa aikaansa ja ympäristöään avoimen uteliaasti ja antautua ihmettelemään maailman menoa yhdessä muiden kanssa. Risto Rinne (2003, 9) paikantaa aikuiskoulutustutkimuksen "..osaksi sitä yhteiskunnallista maailmaa, jossa aikuiset inmiset elävät ja jota tulisi tutkia". Tutkimuksen 
haasteet liittyvät niin aikuisten elämänolosuhteiden kuin yhteiskunta- ja koulutuspoliittisiin muutoksiin. Norjalainen pitkän linjan aikuiskasvatustutkija Odd Nordhaug $(1993,5)$ hahmottelee aikuiskasvatuksen tutkimuskohteeksi aikuisen oppimisen monimuotoisena sosiaalisena ilmiönä. Tämän tutkimuskohteen tarkasteluun tarvitaan hänen mukaansa monia eri tieteenaloja ja näkökulmia. Stephen Brookfieldin (1996) mukaan olemme tulleet sen tien päähän, jossa aikuiskasvatus(tutkimus)ta tulee tarkastella erillisenä ja itseriittoisena tieteenalana, jonka puitteissa tutkijat väittävät hallitsevansa jotain erityistä, jotain mitä muut eivät voi ymmärtää.

\section{Lähteet}

Belzer, A. \& St. Clair, R. (2005). Back to the future: implications of the neopositivist research agenda for adult basic education. Teachers College Record, 107 (6), 1393-1411.

Blunt, A. \& Lee, J-A. (1994). The contribution of graduate student reserach to Adult Education/Adult Education Quarterly 1969-1988. Adult Education Quarterly, 44 (3), 125-144.

Boyd, R. D \&Apps, J.W. (1980). Redefining the discipline of adult education. San Francisco: Jossey-Bass.

Bron, A. (2005). Paradigm change in adult education research. TeoksessaA. Heikkinen (toim.) Aikuiskasvatuksen tutkimuspolut. Kansanvalistusseura, 18-34.

Brookfield, S. (1996). Postscript: An agenda for research and policy. TeoksesaA. Tuijnman, (Ed.) International encyclopedia of adult education and training. Tarrytown, N.Y.: Elsevier Science, Inc.889-895.

Filander, K. (2005). Tutkimuksen muuttuvat tähtäyspisteet. TeoksessaA. Heikkinen (toim.) Aikuiskasvatuksen tutkimuspolut. Kansanvalistusseura, 207-225.

Kivinen, O \& Rinne, R. (1995). Mitä aikuiskasvatustutkimus on? Aikuiskasvatus, 15 (4) 255-264.

Manninen, J. Kauppi, A. Puurula, A\& Kontiainen, S. (2003). Lukijalle. Teoksessa J. Manninen, A. Kauppi, A. Puurula \& S. Kontiainen (toim.) Aikuiskasvatus tutkijoiden silmin tutkimusta 2000-luvun taitteessa. Kansanvalistusseura, 7-8.

Mitä on aikuiskasvatus tänään. (2004). Aikuis- kasvatuksen 6. tutkijatapaamisen abstraktikirja. Jyväskylän yliopisto.

Mohorcic Spolar. V. A. (2001). Challenges and research in the Nordic countries. Book review. Studies in the Education of Adults, 33 (2), 233-234.

Nordhaug, O. (1993). Livslang laering: forskningsmessige utfordringar. Teoksessa V. Haugerud \& J. Kvam (red.) Livslang laering. En antologi on voksenoplaeringens mangfald og enhet. Trondheim: Norsk voksenpedagogisk forskningsinstitutt, 5-23.

Quigley, B. A. (1997) The role of research in the practice of adult education. New Directions for Adult and Continuing Education, Spring 1997 (73), 3-22.

Raivola, R. (1998). Uutta ja vanhaa, omaa ja varastettua, ehkä vähän sinistäkin! Aikuiskasvatus, 18(1), 2-3.

Rantalaiho, K. (1995). Aikuiskasvatustutkimus pitkällä marssillaan. Aikuiskasvatus, 15 (4), 271-272.

Rinne, R. (2003). Arjen, työn ja kulttuuristen merkitysten jäljillä. Haasteita 2000-luvun aikuiskoulutustutkimukselle. Teoksessa J. Manninen, A. Kauppi, A. Puurula \& S. Kontiainen (toim.) Aikuiskasvatus tutkijoiden silmin - tutkimusta 2000-luvun taitteessa. Kansanvalistusseura, 9-40.

Rose, A. D. (2000). What is the state of adult education research today? Adult Learning, 11 (4), 28-29.

Rubensson, K. (2000). Revisiting the map of the territory. Teoksessa Proceedings of the 41st Annual Adult Education Research Conference. Vancouver: University of British Columbia, 397-401.

Tuomisto, J. (1998). Suomalaisen aikuiskasvatustieteen perustan laskijat: Zachris Castrén, Urpo Harva ja Aulis Alanen. Kasvatus, 29 (1), 72-85.

Tuomisto, J. (2005). Searching for a new paradigm of adult education. Teoksessa A. Heikkinen (toim.) Aikuiskasvatuksen tutkimuspolut. Kansanvalistusseura, 35-44.

Vaherva, T. (1995). Onko aikuiskasvatustiede edistynyt? Määritelkäämme edistyksen tuntomerkit. Aikuiskasvatus, 15 (4) 265-270. 